\title{
Optimization of the Material Removal Rate and Electrode Wear Ratio in Electrical Discharge Machining of Reaction-bonded Silicon Carbide by Response Surface Methodology

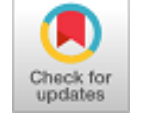

\author{
Z. Nurlishafiqa, P. J. Liew, Q. Ahsan
}

\begin{abstract}
Reaction-bonded silicon carbide (RB-SiC) is widely used as moulding dies material in many industries thanks to its excellent properties. Nevertheless, because of its high hardness and brittleness, it is extremely hard to be machined with high accuracy and good surface finish. Therefore, electrical discharge machining (EDM) has been chosen as an alternative method to machine the RB-SiC. In the present study, an experimental investigation has been conducted to optimize and validate the EDM parameters on the MRR and EWR of low conductivity RB-SiC in EDM. The new $\mathrm{Cu}-1.0$ wt. \% CNF composite electrode that fabricated via powder metallurgy (PM) process was used as the electrode. The experiments were systematically conducted by face-cubic centre (FCC) approach of response surface methodology (RSM). The mathematical models for MRR and EWR were developed in this study. In addition, analysis of variance (ANOVA) was also figured out to check the significance of the models. Three experiments were conducted as the confirmation test to determine the error percentage of MRR and EWR. Based on the results, only 3.06\% and 3.93\% errors were determined for both MRR and EWR, respectively. The optimum conditions for multi responses (MRR and EWR) were found to be at a current of $6 \mathrm{~A}$, voltage of $22 \mathrm{~V}$, and pulse on-time of $12 \mu \mathrm{s}$. The findings of this study provide an important reference to the manufacturing industries, especially mould and die industry.
\end{abstract}

Keywords: Electrical Discharge Machining (EDM), Electrode Wear Ratio (EWR), Material Removal Rate (MRR), Response Surface Methodology (RSM).

\section{INTRODUCTION}

$\mathrm{N}_{\text {owadays, the most challenging part in the engineering }}$ fields are the fastest revolution changes in materials technologies simultaneously with the numberless changes of quality, performances and economic needs [1-2].

Revised Manuscript Received on April 25, 2020.

* Correspondence Author

Z. Nurlishafiqa, Fakulti-Kejuruteraan Pembuatan, Universiti Teknikal Malaysia Melaka, Hang Tuah Jaya, 76100 Durian Tunggal, Melaka, Malaysia. Email: nurli_shafiqa@yahoo.com

P. J. Liew*, Fakulti-Kejuruteraan Pembuatan, Universiti Teknikal Malaysia Melaka, Hang Tuah Jaya, 76100 Durian Tunggal, Melaka, Malaysia. Email: payjun@utem.edu.my

Q. Ahsan, Fakulti Kejuruteraan Pembuatan, Universiti Teknika Malaysia Melaka, Hang Tuah Jaya, 76100 Durian Tunggal, Melaka, Malaysia.Email:qumrul@utem.edu.my

(C) The Authors. Published by Blue Eyes Intelligence Engineering and Sciences Publication (BEIESP). This is an open access article under the CC BY-NC-ND license (http://creativecommons.org/licenses/by-nc-nd/4.0/)
Reaction-bonded silicon carbide is amazingly hard and brittle ceramic material. This material is the right choice to substitute the silicon for advanced precision machining applications due

to its predominant characteristics such as chemical inertness, high wear resistance and thermal conductivity [3]-[5].

In recent years, electrical discharge machining (EDM) has been chosen as an elective method to machine the materials with high hardness since this process does not require high cutting forces due to non-contact surface between the tool and workpiece [6]-[9]. EDM is one of the most advanced machining in manufacturing field which utilizes a spark of electricity to expel the undesirable materials to make complex shapes [10]-[13].

It was noticed that different EDM process parameters impact the machining outputs such as material removal rate (MRR), surface roughness, and electrode wear ratio (EWR). For example, the influences of EDM parameters on the EDM outputs of $\mathrm{SiC}$ has been done by Luis et al. [14]. The outcomes revealed that MRR is more affected by the present of current density and voltage factors. This may happen due to the higher concentration of discharge energy produced when the intensity increased which lead to the higher MRR. Other than that, higher voltage also will increase the gap width and over-cut because of the breakdown at a wider gap due to the higher electric field. The setting of possible combination of those parameters was difficult to produce optimum MRR and EWR for machining of RB-SiC ceramic.

Therefore, the current work plans to investigate the effect of process parameters on the EDM machining performances of RB-SiC by using $\mathrm{Cu}-1.0$ wt. \% CNF composite electrode that fabricated via powder metallurgy (PM) process. Further, the design of experiment (DOE) using response surface methodology (RSM) was used to investigate the impact of EDM parameters on the machining characteristics.

\section{EXPERIMENTAL DETAILS}

\section{A. Workpiece Material and Electrode}

The workpiece materials used in this study are RB-SiC and $\mathrm{Cu}-1.0$ wt. \% CNF composite electrode that prepared by Liew et al. [15] was used as the electrode.

Published By:

Blue Eyes Intelligence Engineering

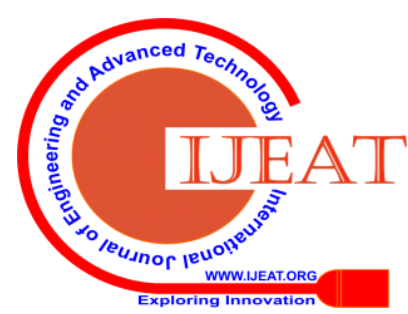




\section{B. Design of EDM Experiments using Response Surface Methodology (RSM)}

RSM is one of the statistical methods to create and analyse the relationship between the various parameters on the machining performances. This is widely used in manufacturing industries in order to develop empirical models for their works.

Based on the previous studies, current $\left(I_{p}\right)$, pulse on-time $\left(T_{o n}\right)$, and voltage $(V)$ are found to influence the MRR and EWR. Table I illustrates the levels of input factors that are selected for the current work. In Table I, the minimum and maximum levels selected for $I_{p}, V$, and $T_{\text {on }}$ were: $5 \mathrm{~A}$ and $7 \mathrm{~A}$, $18 \mathrm{~V}$ and $26 \mathrm{~V}, 8 \mu \mathrm{s}$ and $12 \mu \mathrm{s}$, respectively.

Table- I: Level of process parameters

\begin{tabular}{|c|c|c|c|}
\hline \multirow{2}{*}{ Symbol } & \multirow{2}{*}{ Input factor } & \multicolumn{2}{|c|}{ Level } \\
\cline { 3 - 4 } & & -1 & +1 \\
\hline $\mathrm{A}$ & Current, $I_{p}(\mathrm{~A})$ & 5 & 7 \\
\hline $\mathrm{B}$ & Voltage, $V(\mathrm{~V})$ & 18 & 26 \\
\hline $\mathrm{C}$ & Pulse on-time, $T_{\text {on }}(\mu \mathrm{s})$ & 8 & 12 \\
\hline
\end{tabular}

The experiments were carried out using EDM die-sinking SODICK AQ35L and the experimental setup is shown in Fig. 1. The following parameters were kept constant at a fixed value during the experimental work: $\mathrm{Cu}-1.0 \mathrm{wt}$. \% CNF composite electrode of $6 \mathrm{~mm}$ diameter at positive polarity, machining time was 15 minutes for each experiment and kerosene oil was used as a dielectric medium.

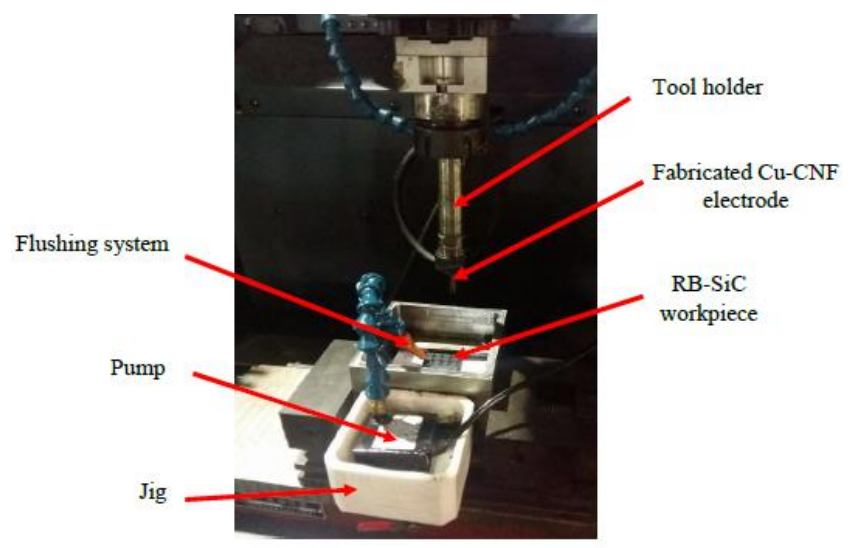

Fig. 1.Experimental setup.

In this research work, seventeen experiments included three center points were designed based on face-cubic center (FCC) by using RSM in design expert software. Three factors and two levels FCC design was used to determine the optimal factors of MRR and EWR. Once the experiment was completed, the workpiece and electrodes were cleaned thoroughly using high pressure air gun. After that, the Mettler Toledo Balance (Model: AB 135 S/Fact) was used to get the final individual weight of electrodes and workpiece for calculation of MRR and EWR. The average value of MRR and EWR were calculated using (1) and (2), respectively.

$$
\begin{gathered}
\text { MRR }=\frac{\sigma_{W} / D}{\rho_{W V / D} \times t} \\
E W R=\frac{m_{q}}{m_{W / p}} \times 100 \%
\end{gathered}
$$

where $m_{w / p}$ is the mass loss of workpiece (g), $\rho_{w / p}$ is the density of workpiece $\left(\mathrm{g} / \mathrm{mm}^{3}\right)$, $\mathrm{t}$ is the machining time which is 15 minutes, and $m_{e}$ is the mass loss of electrode (g).

\section{RESULTS AND DISCUSSION}

\section{A. RSM based DOE and Their Outputs for Machining of RB-SiC}

Based on the outputs generated using RSM, the low and high ranges of parameters, MRR seems to be $0.0096-0.6082$ $\mathrm{mm}^{3} / \mathrm{min}$ and EWR seems to be $5.2 \%$ - 29.03\%. The designed experiments with its outputs are shown in Table II.

Table- II: DOEs and results for machining RB-SiC

\begin{tabular}{|c|c|c|c|c|c|c|}
\hline Std & Run & $\begin{array}{c}\text { A: } \boldsymbol{I}_{\boldsymbol{p}} \\
(\boldsymbol{A})\end{array}$ & $\begin{array}{c}\text { B: } \boldsymbol{V} \\
(\boldsymbol{V})\end{array}$ & $\begin{array}{c}\mathbf{C}: \boldsymbol{T}_{\boldsymbol{~}} \\
(\boldsymbol{\mu} \mathbf{)})\end{array}$ & $\begin{array}{c}\text { R1: MRR } \\
(\mathbf{m m} \text { /min) }\end{array}$ & $\begin{array}{c}\text { R2: EWR } \\
(\mathbf{\%})\end{array}$ \\
\hline 1 & 1 & 5 & 18 & 8 & 0.0257 & 13.01 \\
\hline 2 & 9 & 7 & 18 & 8 & 0.3007 & 23.66 \\
\hline 3 & 16 & 5 & 26 & 8 & 0.0096 & 10.2 \\
\hline 4 & 15 & 7 & 26 & 8 & 0.6082 & 29.03 \\
\hline 5 & 5 & 5 & 18 & 12 & 0.0289 & 5.2 \\
\hline 6 & 11 & 7 & 18 & 12 & 0.3038 & 12.82 \\
\hline 7 & 3 & 5 & 26 & 12 & 0.0425 & 8.5 \\
\hline 8 & 13 & 7 & 26 & 12 & 0.3910 & 16.45 \\
\hline 9 & 4 & 5 & 22 & 10 & 0.0916 & 6.71 \\
\hline 10 & 14 & 7 & 22 & 10 & 0.2814 & 13.7 \\
\hline 11 & 7 & 6 & 18 & 10 & 0.1415 & 15.8 \\
\hline 12 & 8 & 6 & 26 & 10 & 0.2381 & 17.3 \\
\hline 13 & 6 & 6 & 22 & 8 & 0.5039 & 19.54 \\
\hline 14 & 10 & 6 & 22 & 12 & 0.3816 & 17.2 \\
\hline 15 & 12 & 6 & 22 & 10 & 0.5242 & 21.6 \\
\hline 16 & 2 & 6 & 22 & 10 & 0.5338 & 19.72 \\
\hline 17 & 17 & 6 & 22 & 10 & 0.6018 & 15.08 \\
\hline
\end{tabular}

\section{B. Analysis of Process Parameters on MRR for Machining RB-SiC}

Analysis of variance (ANOVA) was implemented to analyse the relation of parameters on the EDM machining performances. The fit summary in ANOVA suggested that the significant analysis of MRR is quadratic model as shown in Table III. This model was transformed into "square root" that has been suggested in box-cox of power transformation.

Table- III: Fit summary for MRR model

\begin{tabular}{|c|c|c|c|c|}
\hline Source & $\begin{array}{c}\text { Standard } \\
\text { deviation }\end{array}$ & R-Squared & $\begin{array}{c}\text { Adjusted } \\
\text { R-Squared }\end{array}$ & $\begin{array}{c}\text { Predicted } \\
\text { R-Squared }\end{array}$ \\
\hline Linear & 0.18 & 0.5295 & 0.4209 & 0.2567 \\
\hline 2FI & 0.20 & 0.5565 & 0.2904 & -0.9731 \\
\hline Quadratic & 0.11 & 0.9053 & 0.7835 & 0.3197 \\
\hline Cubic & 0.13 & 0.9455 & 0.7091 & -82.6227 \\
\hline
\end{tabular}

ANOVA in Table IV shows that the F-value of this MRR model is 7.43 which indicates the model is significant. Besides that, when the values of "P-value" is less than 0.0500 , it shows that the terms are significant and vice-versa. In this experiment, only $\mathrm{A}, \mathrm{A}^{2}$ and $\mathrm{B}^{2}$ were significant model terms. Other than that such as $\mathrm{B}, \mathrm{C}, \mathrm{AB}, \mathrm{AC}, \mathrm{BC}$, and $\mathrm{C}^{2}$ are not significant terms and it can be eliminated from the models. 
Table- IV: ANOVA on MRR for machining RB-SiC

\begin{tabular}{|c|c|c|c|c|c|c|}
\hline Source & $\begin{array}{l}\text { Sum of } \\
\text { squares }\end{array}$ & DF & $\begin{array}{c}\text { Mean of } \\
\text { square }\end{array}$ & F-value & P-value & \\
\hline Model & 0.78 & 9 & 0.087 & 7.43 & 0.0075 & $\mathrm{a}$ \\
\hline $\mathrm{A}-I_{p}$ & 0.44 & 1 & 0.44 & 37.68 & 0.0005 & $\mathrm{a}$ \\
\hline $\mathrm{B}-\mathrm{V}$ & 0.015 & 1 & 0.015 & 1.31 & 0.2899 & \\
\hline $\mathrm{C}-T_{\text {on }}$ & $1.588 \mathrm{E}-003$ & 1 & $1.588 \mathrm{E}-003$ & 0.14 & 0.7233 & \\
\hline $\mathrm{AB}$ & 0.014 & 1 & 0.014 & 1.18 & 0.3137 & \\
\hline $\mathrm{AC}$ & $9.087 \mathrm{E}-003$ & 1 & $9.08 \mathrm{E}-003$ & 0.78 & 0.4071 & \\
\hline $\mathrm{BC}$ & 4.337E-004 & 1 & 4.337E-004 & 0.037 & 0.8527 & \\
\hline $\mathrm{A}^{2}$ & 0.089 & 1 & 0.089 & 7.61 & 0.0281 & $\mathrm{a}$ \\
\hline $\mathrm{B}^{2}$ & 0.074 & 1 & 0.074 & 6.37 & 0.0395 & $\mathrm{a}$ \\
\hline $\mathrm{C}^{2}$ & 0.011 & 1 & 0.011 & 0.97 & 0.3575 & \\
\hline Residual & 0.082 & 7 & 0.012 & & & \\
\hline $\begin{array}{l}\text { Lack of } \\
\text { fit }\end{array}$ & 0.080 & 5 & 0.016 & 20.22 & 0.0478 & \\
\hline $\begin{array}{l}\text { Pure } \\
\text { Error }\end{array}$ & $1.59 \mathrm{E}-003$ & 2 & 7.931E-004 & & & \\
\hline Total & 0.86 & 16 & & & \multicolumn{2}{|c|}{\begin{tabular}{l|l}
16 & \\
\multicolumn{2}{|c|}{ Adj. R-Squared: 0.7835}
\end{tabular}} \\
\hline $\begin{array}{l}\text { R-Squared } \\
\text { Pred. R-Sc } \\
{ }^{\text {a }} \text { Significant. }\end{array}$ & $\begin{array}{l}9053 \\
\text { re:0.3197 }\end{array}$ & & $\begin{array}{l}\text { R-Squared: } \\
\text { q. Precision: }\end{array}$ & $\begin{array}{l}7835 \\
207\end{array}$ & & \\
\hline
\end{tabular}

Table $\mathrm{V}$ shows the new ANOVA on the MRR after eliminated the insignificant terms. From this table, it shows that the model is significant because the F-value of this MRR model is 18.95 that suggested by the new ANOVA. Besides that, the "lack-of-fit F-value" of 14.67 indicated that the "lack of fit" was not significant relative to the pure error. The actual mathematical equation that developed for MRR was shown in (3):

$$
\begin{aligned}
& \text { Sqrt }(M R R)=-10.9403+2.1313\left(I_{p}\right)+ \\
& 0.4075(V)-0.1601\left(I_{p}\right)^{2}-\left(9.039 \times 10^{-3}\right)(V)^{2}
\end{aligned}
$$

Table- V: New ANOVA on the MRR after eliminated the insignificant terms

\begin{tabular}{|c|c|c|c|c|c|c|}
\hline Source & $\begin{array}{c}\text { Sum of } \\
\text { squares }\end{array}$ & DF & $\begin{array}{c}\text { Mean of } \\
\text { square }\end{array}$ & F-value & P-value & \\
\hline Model & 0.75 & 4 & 0.19 & 18.95 & $<0.0001$ & ${ }^{\mathrm{a}}$ \\
\hline $\mathrm{A}-\mathrm{Ip}$ & 0.44 & 1 & 0.44 & 44.78 & $<0.0001$ & $\mathrm{a}$ \\
\hline $\mathrm{B}-\mathrm{V}$ & 0.015 & 1 & 0.015 & 1.56 & 0.2359 & \\
\hline $\mathrm{A}^{2}$ & 0.078 & 1 & 0.078 & 7.90 & 0.0157 & $\mathrm{a}$ \\
\hline $\mathrm{B}^{2}$ & 0.063 & 1 & 0.063 & 6.44 & 0.0260 & \\
\hline Residual & 0.12 & 12 & $9.831 \mathrm{E}-003$ & & & \\
\hline $\begin{array}{c}\text { Lack of } \\
\text { fit }\end{array}$ & 0.12 & 10 & 0.012 & 14.67 & 0.0654 & \\
\hline $\begin{array}{c}\text { Pure } \\
\text { Error }\end{array}$ & $1.59 \mathrm{E}-003$ & 2 & $37.93 \mathrm{E}-004$ & & & \\
\hline Total & 0.86 & 16 & & & & \\
\hline
\end{tabular}

R-Squared: $0.8633 \quad$ Adj. R-Squared: 0.8178

Pred. R-Square:0.6767 Adeq. Precision: 11.221

${ }^{\text {a }}$ Significant.

Fig. 2 shows the response surface model on the MRR between $I_{p}$ and $V$ factors when the $T_{o n}$ at $10 \mu \mathrm{s}$. From the combined response model illustrated in this figure, it can be seen that at lower $I_{p}$, the MRR did not change at any value of $\mathrm{V}$. However, at a higher $I_{p}$, the MRR initially increased with an increase of $V$ and then decreased when the $V$ increased further. During the EDM process, the increase of $I_{p}$ might increase the amount of pulse discharge energy stroked on the workpiece and melted it to remove the material, which in turn increased the MRR [16]. Later, the ever-increasing removed material debris plugged the machined hole. Eventually, it affected the machining efficiency and reduced the MRR.

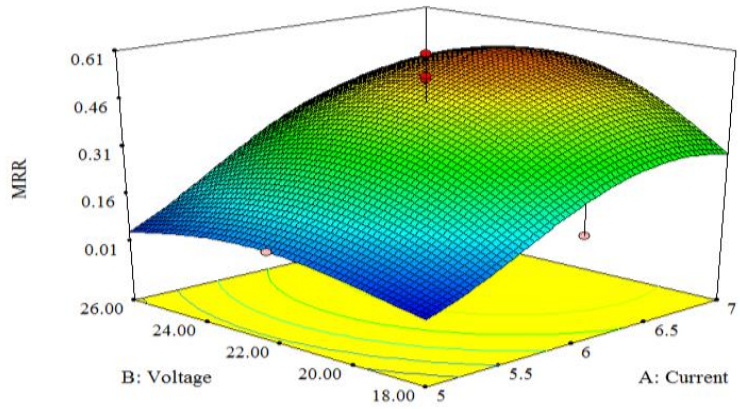

Fig. 2.Response surface on the MRR between $I_{p}$ and $V$.

Fig. 3 shows the response surface model on the MRR between $V$ and $T_{o n}$ when the $I_{p}$ at 6A. From this figure, it can be noticed that at lower $V$, the MRR did not vary at any values of $T_{\text {on. }}$. However, when $V$ increased, the MRR will increase. It is noticed that the increases in the breakdown voltage usually will result an increase in both the discharge energy and the work gap, giving the later a better flushing of the EDM debris. Therefore, the MRR increased. However, when the $V$ is beyond $22 \mathrm{~V}$, the MRR started to decrease again.

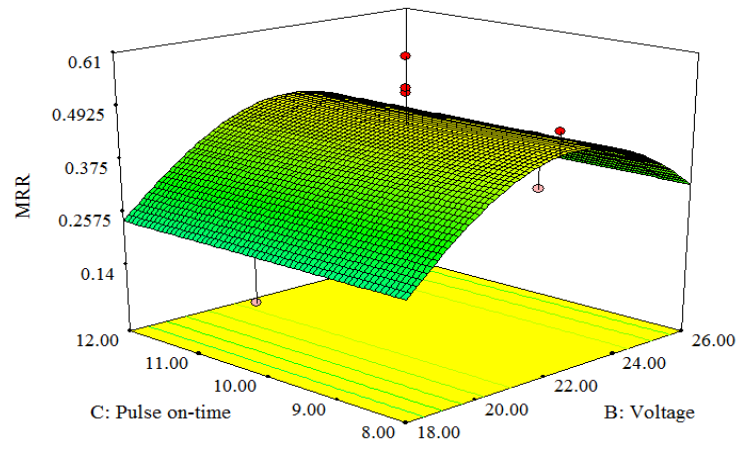

Fig. 3.Response surface on the MRR between $V$ and $T_{o n}$.

\section{Analysis of Process Parameters on EWR for Machining RB-SiC}

The fit summary in ANOVA suggested that the significant analysis of EWR was a linear model as shown in Table VI. Besides that, the ANOVA results for EWR are shown in Table VII.

Table- VI: Fit summary for EWR model

\begin{tabular}{|c|c|c|c|c|}
\hline Source & $\begin{array}{c}\text { Standard } \\
\text { deviation }\end{array}$ & R-Squared & $\begin{array}{c}\text { Adjusted } \\
\text { R-Squared }\end{array}$ & $\begin{array}{c}\text { Predicted } \\
\text { R-Squared }\end{array}$ \\
\hline Linear & 3.90 & 0.6731 & 0.5976 & 0.4748 \\
\hline 2FI & 4.03 & 0.7320 & 0.5711 & 0.2971 \\
\hline Quadratic & 3.61 & 0.8845 & 0.7360 & 0.2372 \\
\hline Cubic & 3.68 & 0.9327 & 0.6412 & -46.7171 \\
\hline
\end{tabular}

\begin{tabular}{|c|c|c|c|c|c|c|}
\hline Source & $\begin{array}{c}\text { Sum of } \\
\text { squares }\end{array}$ & DF & $\begin{array}{c}\text { Mean } \\
\text { of } \\
\text { square }\end{array}$ & F-value & P-value & \\
\hline Model & 395.21 & 2 & 197.61 & 13.18 & 0.0006 & $\mathrm{a}^{\mathrm{a}}$ \\
\hline $\mathrm{A}-I_{p}$ & 270.82 & 1 & 270.82 & 18.06 & 0.0008 & $\mathrm{a}$ \\
\hline $\mathrm{C}-T_{\text {on }}$ & 124.40 & 1 & 124.40 & 8.30 & 0.0121 & $\mathrm{a}$ \\
\hline Residual & 209.90 & 14 & 14.99 & & & \\
\hline Lack of fit & 187.37 & 12 & 15.61 & 1.39 & 0.4939 & \\
\hline Pure Error & 22.52 & 2 & 11.26 & & & \\
\hline Total & 605.11 & 16 & & & & \\
\hline $\begin{array}{l}\text { R-Squared: } 0.6 \\
\text { R-Squared: } 0.6 \\
\text { Pred. R-Squar } \\
\text { Precision: } 10.7 \\
{ }^{a} \text { Significant. }\end{array}$ & $\begin{array}{l}31 \\
36 \\
.4933 \\
5\end{array}$ & $\begin{array}{l}\text { Adj. } \\
\text { Adeq. }\end{array}$ & & & & \\
\hline $\begin{array}{l}\text { Published B } \\
\text { Blue Eyes Ir } \\
\text { \& Sciences } \\
\text { (C) Copvriah }\end{array}$ & lication & o & & & & \\
\hline
\end{tabular}

Table- VII: ANOVA on EWR for machining RB-SiC 


\section{Optimization of the Material Removal Rate and Electrode Wear Ratio in Electrical Discharge Machining of}

Reaction-bonded Silicon Carbide by Response Surface Methodology

This model was developed at 95\% confidence level. The model F-value of 13.18 implied that the model was significant. The P-value which was less than 0.05 indicated that the model terms were significant and vice-versa. In this case, the significant model terms for EWR were A and C only. Therefore, the actual mathematical equation developed for EWR was shown in (4):

$$
E W R=+2.02982+5.204\left(I_{p}\right)-1.7635\left(T_{\text {on }}\right)
$$

Fig. 4 shows the response surface model between $I_{p}$ versus $V$ on EWR of RB-SiC when the $T_{\text {on }}$ at $10 \mu$ s. It can be noticed that at lower $I_{p}$, the EWR did not change at any value of $\mathrm{V}$. However, at higher $I_{p}$ and higher $\mathrm{V}$, the higher EWR has been obtained. This condition might occur due to the higher generation of discharge energy which leading to the higher EWR. Fig. 5 illustrates the surface response on the EWR between $\mathrm{V}$ and $T_{\text {on }}$. From this figure, it shows that the lowest EWR can be obtained at lower $\mathrm{V}$ and higher $T_{\text {on }}$. During the EDM process, when the $T_{\text {on }}$ value was higher, more debris was accumulated inside the gap between the electrode and workpiece produced frequent short circuit. So, this condition leading to the reduction of EWR.

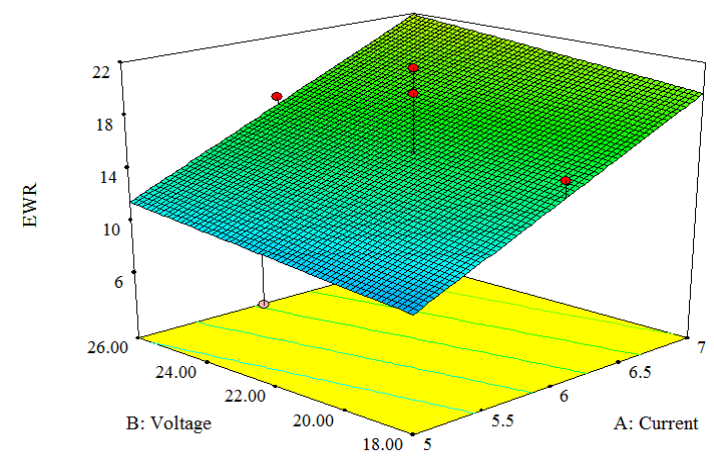

Fig. 4.Response surface on the EWR between $I_{p}$

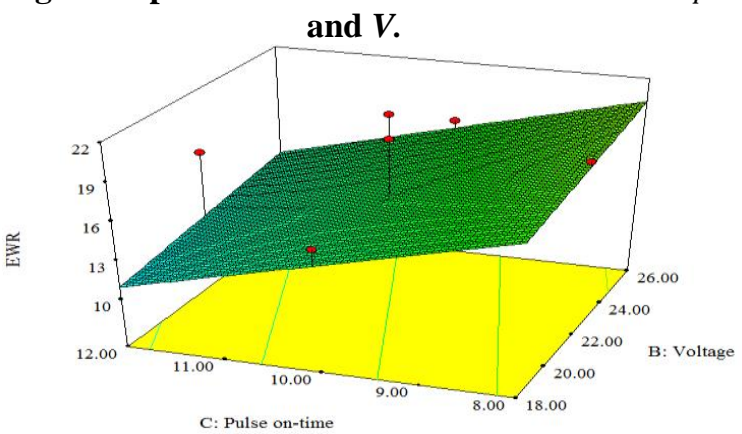

Fig. 5.Response surface on the EWR between $V$ and $T_{o n}$.

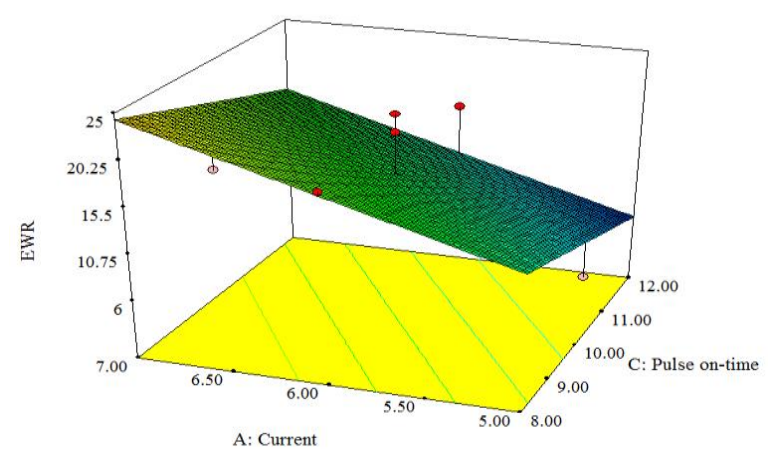

Fig. 6.Response surface on the EWR between $I_{p}$ and $T_{o n}$.

Besides that, the response surface on the EWR between $I_{p}$ and $T_{\text {on }}$ was shown in Fig. 6. The result shows that the lowest EWR generated at lower $I_{p}$ and higher $T_{\text {on }}$. When the $I_{p}$ density was lower, leading to the lower discharge energy, so less EWR has been produced [17].

\section{Optimization Parameters of Multi-response on the MRR and EWR}

Based on the results that generated by RSM, the optimum EDM parameters in this study were current at $6 \mathrm{~A}$, voltage at $22 \mathrm{~V}$ and pulse on-time at $12 \mu \mathrm{s}$ as shown in Table VIII. The predicted values for MRR and EWR were calculated using (3) and (4), respectively. So, in order to validate these optimization parameters, three experiments were performed for a confirmation test. The experimental values for MRR and EWR were calculated using (1) and (2), respectively. The results of the confirmation test are tabulated in Table IX.

Table- VIII: Optimization EDM parameters on MRR and EWR

\begin{tabular}{|c|c|c|c|c|c|}
\hline $\begin{array}{c}\boldsymbol{I}_{\boldsymbol{p}} \\
(\mathbf{A})\end{array}$ & $\begin{array}{c}\boldsymbol{V} \\
(\mathbf{V})\end{array}$ & $\begin{array}{c}\boldsymbol{T}_{\text {on }} \\
(\boldsymbol{\mu s})\end{array}$ & $\begin{array}{c}\text { MRR } \\
\left(\mathbf{m m}^{3} / \mathbf{m i n}\right)\end{array}$ & $\begin{array}{c}\text { EWR } \\
(\mathbf{\%})\end{array}$ & Desirability \\
\hline 6 & 22 & 12 & 0.4766 & 12.48 & 0.777 \\
\hline
\end{tabular}

Table- IX: Results of confirmation test

\begin{tabular}{|c|c|c|c|c|c|c|}
\hline \multirow{2}{*}{ Response } & \multirow{2}{*}{ Pred. } & \multicolumn{3}{|c|}{ Experimental } & \multirow{2}{*}{ Mean } & \multirow{2}{*}{$\begin{array}{c}\text { Error } \\
(\%)\end{array}$} \\
\hline & & 1 & 2 & 3 & & \\
\hline MRR & 0.4766 & 0.492 & 0.409 & 0.485 & 0.462 & 3.06 \\
\hline EWR & 12.48 & 14.26 & 11.94 & 12.70 & 12.97 & 3.93 \\
\hline
\end{tabular}

From this table, the test percentage of the overall experiment lies within 3.06\% and 3.93\% for both MRR and EWR, respectively. The values also gave a close result to each other among the overall experiment mean and predicted values. Thus, it validated the combination of the obtained optimum EDM parameters of RB-SiC because the percentage errors of MRR and EWR were less than 5\%, which is less than significant level.

\section{CONCLUSION}

The EDM machining performance mainly depends on the machining parameters. This paper investigated the influence of EDM parameters on the MRR and EWR of low conductivity RB-SiC ceramic material. RSM has been used as the statistical method to develop the mathematical models to identify the significant parameters of the EDM machining performances. Based on this experimental study, the following conclusions can be drawn:

- From ANOVA, $I_{p}, I_{p}^{2}$ and $V^{2}$ were the significant parameter for MRR. Meanwhile, for EWR, $I_{p}$ and $T_{o n}$ were the significant parameters for EDM of RB-SiC.

- The optimum parameters for MRR and EWR were found at a current of $6 \mathrm{~A}$, voltage of $22 \mathrm{~V}$, and pulse on-time of $12 \mu \mathrm{s}$.

\section{ACKNOWLEDGMENT}

The authors are grateful for the financial support provided by Universiti Teknikal Malaysia Melaka, under the grant number RACE/F3/TK4/FKP/F00300 for the accomplishment of this work.

Published By:

Blue Eyes Intelligence Engineering \& Sciences Publication

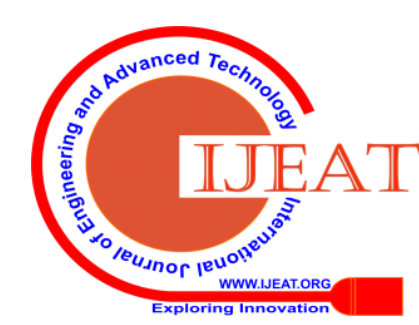




\section{REFERENCES}

1. P. Chaudhury, S. Samantaray, "Role of carbon nano tubes in surface modification on electrical discharge machining - A review," $5^{\text {th }}$ Int. Conf. Mater. Process. Characterization (ICMPC 2016), Materials Today: Proceedings 4, 2017, pp. 4079-4088.

2. S. K. Choudhary, R. S. Jadoun, "Current advanced research development of electrical discharge machining (EDM): A review," Int. J. Research in Advent Tech., vol. 2, 2014, pp. 101-116.

3. S. Goel, J. Yan, X. Lou, A. Agrawal, "Incipient plasticity in 4H-SiC during quasistatic nanoindentation," J. Mech. Behaviour Biomedical Materials, vol. 34, 2014, pp. 330-337.

4. S. Agarwal, P. V. Rao, "Experimental investigation of surface/subsurface damage formation and material removal mechanisms in sic grinding," Int. J. Machine Tools and Manuf., vol. 48, 2008, pp. 698-710.

5. M. R. Abdul Razak, P. J. Liew, N. I. S. Hussien, Q. Ahsan, "Effect of surfactant on EDM of low conductivity reaction-bonded silicon carbide," Key Engineering Materials, vol. 701, 2016, pp. 107-111.

6. K. Saxena, A. S. Srivastava, S. Agarwal, "Experimental investigation into the micro-EDM characteristics of conductive SiC," Ceramics Int. vol. 42, 2016, pp. 1597-1610.

7. R. Ji, Y. Liu, Y. Zhang, F. Wang, "Machining performance of silicon carbide ceramic in end electrical discharge milling," Int. J. Refractory Metals and Hard Materials, vol. 29, 2011, pp. 117-122.

8. P. J. Liew, J. Yan, T. Kuriyagawa, "Carbon nanofiber assisted micro electro discharge machining of reaction-bonded silicon carbide," $J$. Mater. Process. Tech., vol. 213, 2013, pp. 1076-1087.

9. A. K. Khanra, B. R. Sarkar, B. Bhattacharya, L. C. Pathak, M. M. Godkhindi, "Performance of ZrB2-Cu composite as an EDM electrode," J. Mater. Process. Techn., vol. 183, 2007, pp. 122-126.

10. D. Hanaoka, Y. Fukuzawa, C. Ramirez, P. Miranzo, M.I. Osendi, M. Belmonte, "Electrical discharge machining of ceramic/carbon nanostructure composites," Procedia CIRP, vol. 6, 2013, pp. 95-100.

11. M. S. Rasheed, "Comparison of micro-holes produced by micro-EDM with laser machining," Int. J. Sci. and Modern Engineer., vol. 1, 2013, pp. 14-18.

12. S. Ganguly, "A detailed review of the current research trends in electrical discharge machining (EDM)," Proceeding of the National Conference on Trends and Advances in Mechanical Engineering, 2012, pp. 657-669.

13. T. Sultan, A. Kumar, R. D. Gupta, "Material removal rate, electrode wear rate and surface roughness evaluation in die sinking EDM with hollow tool through response surface methodology," Int. J. Manuf. Engineer., 2014, pp. 1-16.

14. C. J. Luis, I. Puertas, G. Villa, "Material removal rate and electrode wear study on the EDM of silicon carbide," J. Mater. Process. Tech., vol. 164 - 165, 2005, pp. 889-896.

15. P. J. Liew, Z. Nurlishafiqa, Q. Ahsan, "Preparation and characterization of carbon nanofiber reinforced copper composite electrodes via powder metallurgy process for electrical discharge machining applications," Int. J. Applied Engineering Research, vol. 12, 2017, pp. 2253-2261.

16. S. S. Habib, "Study of the parameters in electrical discharge machining through response surface methodology approach," Applied Math. Modelling, vol. 33, 2009, pp. 4397-4407.

17. A. K. Dilshad, H. Mohammad, "Effect of tool polarity on the machining characteristics in electric discharge machining of silver steel and statistical modelling of the process," Int. J. Engineer. Sci. Technol., vol. 3, 2011, pp. 5001-5010.

\section{AUTHORS PROFILE}

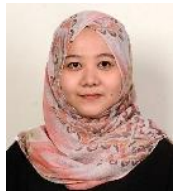

Z. Nurlishafiqa was graduated her Master's degree in Manufacturing Engineering (Manufacturing Process) from Universiti Teknikal Malaysia Melaka (UTeM), Melaka, Malaysia, in Year 2017. Her research interest includes the fabrication of nanocomposite electrodes in electrical discharge machining (EDM) application for machining low conductive materials

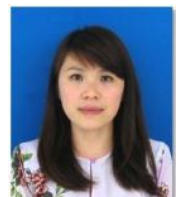

P. J. Liew received her B.Eng Mechanical (Manufacturing) Engineering from Kolej Universiti Teknologi Tun Hussein Onn in 2006 and M.Sc. Manufacturing Systems Engineering from Coventry University, UK in 2007. Later in 2013, she completed her Ph.D in Mechanical Systems and Design from Tohoku University, Japan. Her research works include machining of low conductivity ceramic materials using micro/conventional electrical discharge machining (EDM) and application of nanofluid in machining processes.

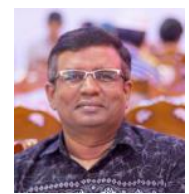

Q. Ahsan obtained his Bachelor (1986) and Master's degree (1987) in Metallurgical Engineering from Bangladesh University of Engineering and Technology (BUET), Dhaka securing distinct position among the cohort. He pursued his Ph.D at the University of Birmingham, UK in 1997 under a Commonwealth Scholarship Program. His research experience so far spreads over a number of key areas specially processing of non-conventional materials, sustainable development of green composite materials, non-destructive evaluation of materials, and failure analysis of engineering materials.

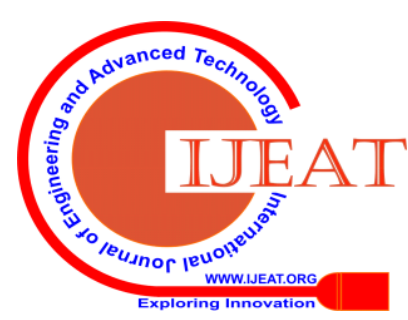

